\title{
Extensions for Distributed Moving Base Driving Simulators
}

by

\author{
Anders Andersson
}

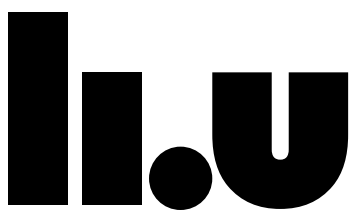

LINKÖPING UNIVERSITY

\footnotetext{
Department of Computer and Information Science

Linköping University

SE-581 83 Linköping, Sweden
} 
This is a Swedish Licentiate's Thesis

Swedish postgraduate education leads to a doctor's degree and/or a licentiate's degree. A doctor's degree comprises 240 ECTS credits (4 year of full-time studies).

A licentiate's degree comprises 120 ECTS credits.

Copyright (C) 2017 Anders Andersson

ISBN 978-91-7685-524-9

ISSN 0280-7971

Printed by LiU Tryck 2017

URL: http://urn.kb.se/resolve?urn=urn:nbn:se:liu:diva-136146 


\begin{abstract}
Modern vehicles are complex systems. Different design stages for such a complex system include evaluation using models and submodels, hardwarein-the-loop systems and complete vehicles. Once a vehicle is delivered to the market evaluation continues by the public. One kind of tool that can be used during many stages of a vehicle lifecycle is driving simulators.

The use of driving simulators with a human driver is commonly focused on driver behavior. In a high fidelity moving base driving simulator it is possible to provide realistic and repetitive driving situations using distinctive features such as: physical modelling of driven vehicle, a moving base, a physical cabin interface and an audio and visual representation of the driving environment. A desired but difficult goal to achieve using a moving base driving simulator is to have behavioral validity. In other words, "A driver in a moving base driving simulator should have the same driving behavior as he or she would have during the same driving task in a real vehicle.".
\end{abstract}

In this thesis the focus is on high fidelity moving base driving simulators. The main target is to improve the behavior validity or to maintain behavior validity while adding complexity to the simulator. One main assumption in this thesis is that systems closer to the final product provide better accuracy and are perceived better if properly integrated. Thus, the approach in this thesis is to try to ease incorporation of such systems using combinations of the methods hardware-in-the-loop and distributed simulation. Hardware-inthe-loop is a method where hardware is interfaced into a software controlled environment/simulation. Distributed simulation is a method where parts of a simulation at physically different locations are connected together. For some simulator laboratories distributed simulation is the only feasible option since some hardware cannot be moved in an easy way.

Results presented in this thesis show that a complete vehicle or hardwarein-the-loop test laboratory can successfully be connected to a moving base driving simulator. Further, it is demonstrated that using a framework for distributed simulation eases communication and integration due to standardized interfaces. One identified potential problem is complexity in interface wrappers when integrating hardware-in-the-loop in a distributed simulation framework. From this aspect, it is important to consider the model design and the intersections between software and hardware models. Another important issue discussed is the increased delay in overhead time when using a framework for distributed simulation.

This work has been supported by the Swedish National Road and Transport Research Institute (VTI) and the ViP driving simulation centre (Virtual Prototyping and Assessment by Simulation), which is financed by the Swedish Governmental Agency for Innovation Systems (grant number 2011-03994) and the centre partners.

Department of Computer and Information Science

Linköping University

SE-581 83 Linköping, Sweden 



\section{Acknowledgements}

First, I want to thank my main supervisor Peter Fritzson for enabling this joint work between the Swedish National Road and Transport Research Institute (VTI) and Linköping University and for the many insightful thoughts and guidance. I also want to thank my supervisor at VTI Jonas Jansson for giving me this opportunity and for his support and valuable input. Further, I want to thank my supervisor Lena Buffoni for the many valuable discussions, disagreements and improvement suggestions throughout this work.

When connecting a moving base driving simulator to the chassis dynamometers I recieved help from Håkan Sehammar, Peter Nyberg and Per Öberg, which I am grateful for. Further, I want to thank Jonas Andersson Hultgren, Erik Olsson, Rickard Leandertz, Magnus Johansson, Martin Johansson, Steve Betnér, Ola Jakobson, and Fredrik Rolff for the efforts in creating the distributed simulation platform using HLA. Also, thanks to Sogol Kharrazi for help with proofreading and constructive feedback.

I am also very grateful to all former and current collegues at FTS/SIM and members at PELAB for contributing to a fun working environment. Many enriching topics, important and/or irrelevant, have been dealt with during fika.

Finally, I would like to thank family and friends for encouragement and support during tough times. I also want to thank Maria and our son Oscar for a bigger picture of life! 



\section{Contents}

Introduction 1

1 Introduction 3

1.1 Driving Simulators . . . . . . . . . . . . . . . . . . 4

1.1.1 Driving Simulators at VTI . . . . . . . . . . . 6

1.2 Physical Modelling . . . . . . . . . . . . . . . . 7

1.3 Hardware-In-the-Loop . . . . . . . . . . . . . . . . . . . 10

1.4 Distributed Simulation . . . . . . . . . . . . . . . . . . . . 11

1.5 Contributions ...................... 12

1.5.1 Paper A .................... 12

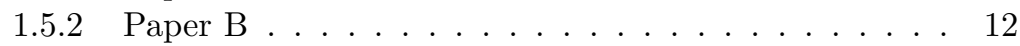

1.5.3 Paper C...................... 13

1.5.4 Distributed Simulation Demonstrations . . . . . . . . 13

1.6 Future Work . . . . . . . . . . . . . . . . . . 15

1.7 References..................... 16

$\begin{array}{ll}\text { Publications } & 21\end{array}$

A Vehicle Powertrain Test Bench Co-Simulation with a Moving Base Simulator Using a Pedal Robot 23

1 Introduction . . . . . . . . . . . . . . . 25

2 Experimental setup . . . . . . . . . . . . . . 25

2.1 Chassis Dynamometer Lab . . . . . . . . . . 26

2.2 VTI Simulator III . . . . . . . . . . . . . . 30

2.3 Pedal robot . . . . . . . . . . . . . . . 32

2.4 Connection between facilities . . . . . . . . . . . . . 34

2.5 Synchronizing vehicle models . . . . . . . . . . . 34

$2.6 \quad$ Driving mission . . . . . . . . . . . . . . 36

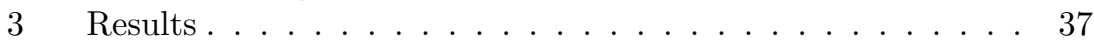

3.1 Network performance . . . . . . . . . . . . 37

3.2 Step response tests of pedal robot . . . . . . . . . 38

3.3 Running the complete system . . . . . . . . . . . . 39

4 Conclusions . . . . . . . . . . . . . . . . . . . 44

5 References....................... 44 
B Models for Distributed Real-Time Simulation in a Vehicle $\begin{array}{ll}\text { Co-Simulator Setup } & 47\end{array}$

1 Introduction . . . . . . . . . . . . . . . . . . . 49

2 Hardware Facilities . . . . . . . . . . . . . . . . 50

$2.1 \quad$ VTI Simulator III . . . . . . . . . . . . . . . 50

$2.2 \quad$ Vehicle Propulsion Laboratory _. . . . . . . . . . . 51

2.3 Chassis Dynamometer Vehicle Model . . . . . . . . . . 52

$2.4 \quad$ Pedal Robot . . . . . . . . . . . . . . . . . . 53

$2.5 \quad$ Network Performance . . . . . . . . . . . . . . . 54

2.6 Modelica Models . . . . . . . . . . . . . . . . . . . . . 55

2.7 Powertrain Model . . . . . . . . . . . . . . . 56

$2.8 \quad$ Estimating Powertrain Model Parameters . . . . . . . 57

$2.9 \quad$ Pedal Robot Model . . . . . . . . . . . . . . . . . . . . 58

2.10 Model of the Chassis Dynamometer Lab . . . . . . . . 59

2.11 Simulator Car Model . . . . . . . . . . . . . . . . . . 59

2.12 Complete Simulator Setup . . . . . . . . . . . . 60

3 Results........................ 61

3.1 Performance of the Chassis Dynamometers Model . . 61

4 Conclusion . . . . . . . . . . . . . . . . 63

$5 \quad$ Future Work . . . . . . . . . . . . . . . . . 63

6 Acknowledgements . . . . . . . . . . . . . . 63

7 References . . . . . . . . . . . . . . . 64

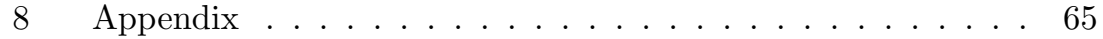

C A Driving Simulation Platform using Distributed Vehicle Simulators and HLA $\quad 69$

1 Introduction . . . . . . . . . . . . . . . . . 71

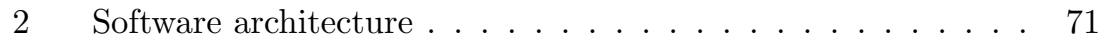

2.1 User needs . . . . . . . . . . . . . . . . . . . . . . 72

$2.2 \quad$ Session Control . . . . . . . . . . . . . . . . . . 73

2.3 Environment Simulator . . . . . . . . . . . . . . . 73

2.4 Driving Simulator . . . . . . . . . . . . . . 74

$2.5 \quad$ Vehicle Simulator . . . . . . . . . . . . . . . . . 75

2.6 Interfaces and communication . . . . . . . . . 75

3 Hardware platforms . . . . . . . . . . . . . . 78

3.1 VTI driving simulators . . . . . . . . . . . . . . . . . 78

$3.2 \quad$ VCC HIL simulator . . . . . . . . . . . . . . . . 79

4 Results. . . . . . . . . . . . . . . 80

4.1 Time measures . . . . . . . . . . . . . . . 80

$4.2 \quad$ Platform flexibility . . . . . . . . . . . . . . . 82

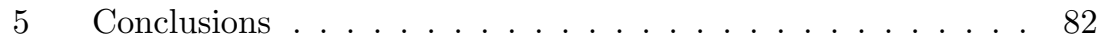

$5.1 \quad$ Future Work . . . . . . . . . . . . . . . . . 83

6 Acknowledgement. . . . . . . . . . . . . . . . 83

7 References . . . . . . . . . . . . . . . . 83 
Introduction 



\section{Chapter 1}

\section{Introduction}

Modern vehicles are complex systems with high demands on quality across different areas, consider e.g. reliability, price, comfort, maneuverability, fun to drive, environmental friendliness, and of course safety. Evaluation of such a complex systems typically starts by testing individual components of the system from a functional aspect. Thus, these individual components are guaranteed to have the "by the first design" intended behavior. Further, evaluation continues with testing combined sets of components, commonly referred to as a system or subsystems. Components or subsystems that do not meet the requirements or do not work as intended are redesigned and the process starts over again by evaluation of the individual components and later the subsystems. If this process of design and refinement was linear it would take extensive time to complete a vehicle unless the first design is correct. To speed up this evaluation process it is run in parallel where simplified models of some components or subsystems can be used in early stages of the process. One issue with simplified models is that they might be too simplified and an incorrect behavior might not be detected. Thus, as the design process continues, simplified components or subsystems will be replaced by more detailed and accurate models or hardware-in-the-loop simulations. At late stages of evaluation, complete hardware subsystems are tested during actual driving conditions, and finally in the latest stage complete vehicle prototypes are tested.

During the described design process several tools are used. One example of such tools is driving simulators, and more specifically, which is the focus in this thesis, high fidelity moving base driving simulators. Studies performed on driving simulators with a human driver typically focus on driver behavior. Interacting with a digital driving environment requires a sense of immersion from the driver. In a high fidelity moving base driving simulator it is possible to present realistic and repetitive driving situations to drivers. This provides a cost effective way of collecting high quality data for analysis. The overall goal in this work is to provide further realism by constructing and exploring 
distributed hardware-in-the-loop platforms, and thus increase the sense of immersion in a high fidelity moving base driving simulator.

The problems that motivate this work are 1) parameterizing complex models are difficult and time-consuming, and 2) complex models are difficult to maintain and adjust. By combining hardware-in-the-loop and distributed simulation the required model complexity can be reduced. Two central research questions addressed in this work are thus the following. First, how to seamlessly integrate hardware-in-the-loop, requiring interfaces at intersections between software models and hardware, while preserving fidelity. Second, investigate if time delays introduced by system decoupling into a distributed set-up can have a negative impact on real-time systems, and if present, how to avoid the negative impact.

This thesis is structured in the following way: the first four subsections introduce the areas of moving base driving simulators, programming languages for model-based development, hardware-in-the-loop simulations, and distributed simulation respectively. In Subsection five of this thesis our contributions are presented. Subsection six presents future work followed by the contributing papers.

\subsection{Driving Simulators}

Simulations and simulators are today common and diverse tools for evaluation of existing systems or system designs. As such, driving simulators range from purely mathematical models running on a single computer to full size moving base driving simulators that take up the physical space of a smaller hangar including several computers, e.g. the National Advanced Driving Simulator (NADS Overview PDF 2015). A driving simulator commonly has a design in between these extremes. Vehicle hardware is also commonly included to various degrees, ranging from simple driver controls to a complete car where techniques such as augmented reality may be explored (Blissing 2016). The focus in this work are human drivers in a high fidelity moving base driving simulator. Such a moving base driving simulator consists of a few distinctive features:

1. A moving base presenting motion cues to the driver.

2. A real cabin for a driver to interact with the simulated vehicle.

3. A visual and auditive (sometimes also haptic) representation of the surrounding environment.

A moving base driving simulator with only one or two degrees of freedom will be referred to as a small moving base simulator. Thus, what is referred to as a moving base driving simulator will have three or more degrees of freedom. How these degrees of freedom are used varies depending on the simulator and its application. The strategy for providing motion feedback 
to the driver is called motion cueing. For an example of a motion cueing strategy see (Fischer et al. 2010).

These distinctive features only describe the top layer of a moving base driving simulator. Other important technical aspects include capabilities of logging of data, a vehicle dynamics model, models for surrounding traffic behavior and digital environments representing actual roads/cities or totally fictional environments. There can also be additional study dependent equipment, such as systems for logging biological signals or tasks for driver distraction. Sometimes the system or component under test is actual hardware that is run as hardware-in-the-loop.

Two of the main benefits of using a moving base driving simulator are the repeatability, so that every driver experiences the same situations, and the possibility to create virtual dangerous situations in a controlled environment. Usually the goal is to study driver behavior during these situations and thus, it is crucial that the driver is immersed into a normal driving behavior. This goal is phrased as the simulator driver behavioral validity in this work:

Simulator driver behavioral validity: A driver in a moving base driving simulator should have the same driving behavior as he or she would have during the same driving task in a real vehicle.

Absolute validity, where there is no statistical difference between driving in a simulator or on the road, is a hard goal to achieve (Törnros et al. 1997). Thus, usually the aim is to achieve behavior validity for specific parts of a simulator study. One example of a study performed at the Swedish National Road and Transport Research Institute (VTI), where the goal of absolute validity was achieved for parts of the study, is (Ahlström et al. 2012). In this study a lot of effort was put into preparations of the simulator since drivers would drive on roads close to Linköping consecutively both in the simulator and outdoors. Thus, the simulator environment had to match the outdoor environment with e.g. landmarks. Also, the vehicle model within the moving base driving simulator was parameterized to match the specific vehicle driven on the road. For certain applications where a specific driving maneuver is known or predicted to occur, the simulator can be optimized for it beforehand, to get closer to absolute validity. As an example the simulator can be prepositioned for curves, see (Hansson et al. 2015), although most cases of normal driving do not allow such optimizations. Since it is often not possible to put this amount of effort into constructing the environment and simulator calibration the goal of the driver perception would be to have relative validity. This means that driver behavior in a driving simulator is relatively correct compared with drivers on the road. As an example consider a driving simulator study comparing two different designs of an active safety system alerting the driver. Assume that one of the systems results in a decreased reaction time when compared to the other system for a specific situation. Then, if relatively valid, the same system will have a decreased reaction time compared to the other system in real driving as well. 
Improving the simulation immersion and perception increases the precision in driving perception and thus aids the validity of the results, but it has to be done in a cost effective way.

\subsubsection{Driving Simulators at VTI}

At VTI moving base driving simulators have been used and developed for more than thirty years starting in 1978 with the presentation of the first construction plans for Sim I which was later completed in 1984. Sim I had a moving base, a visual system, a cabin and a model of a vehicle (Nilsson 1993) but was dismantled several years ago. When continuing the simulator development it became quite clear that simulators and the studies they perform are quite connected and that there will always be limits to what is possible to perform (Nordmark 1994). A common study performed using the VTI moving base driving simulators focuses on driver behavior. For a few examples see an early collection of behavior research (Nilsson 1993), a study of mobile phone usage (Kircher et al. 2004), a study about detection of sleepiness (Fors et al. 2011) and a study evaluating steering feeling in heavy vehicles (Rothhämel 2013). But studies at VTI are not limited to only behavioral studies and several other aspects have been investigated e.g. collision avoidance dynamic performance of trucks on low friction surfaces (Markkula et al. 2013) and visualizations of construction plans for a tunnel (Patten and Mårdh 2012).

Currently there are three operational moving base driving simulators at VTI which are:

Sim II: Sim II was constructed in 1991 to be used as a truck simulator (Nordmark 1992). The simulator provides 3 degrees of freedom for larger motion and a vibration table for road roughness and has been upgraded in several steps improving e.g. the visual and audio system.

Sim III: Further developing the design used in Sim II one more degree of freedom was added when constructing Sim III which was finished in 2003 (Nordmark et al. 2004). The simulator is mostly used as a passenger car simulator with a smooth linear motion with world top performance.

Sim IV: Sim IV was built with a new design combining a hexapod with an xy-table providing large linear motion in the plane (Jansson et al. 2014). The simulator was inaugurated in 2011 and is used with a car or a truck cabin.

In addition to the moving base driving simulators at VTI, smaller driving simulators are also used, e.g. a fixed based driving simulator named SimFoerst.

Although work done in this thesis focuses on road-bound driving simulators, it might be of interest to mention that VTI also develops railway 
train simulators. To reduce the amount of different software and hardware systems, an architecture structure where the train simulators share as much as possible with the driving simulators is desired. An example of hardware interoperability is that the dimensions of one train simulator cabin are such that it is possible to mount the train cabin onto the moving base in Sim III.

\subsection{Physical Modelling}

A model of a physical system should capture essential characteristics for an intended usage. Furthermore, in a broad sense a simulation presents how such a model behaves over time. As such, the name driving simulator specifies the usage of a physically modelled vehicle and its behavior over time. Further, a driving simulator study implies requirements from the study, earlier mentioned as the essential characteristics for the intended usage, and provides requirements on the model. This section gives a presentation of different techniques for modelling of such essential characteristics.

In a moving base driving simulator it is important to present realistic dynamic behavior of the driven vehicle to the driver. This is typically done by implementing a mathematical software representation of the physical model of the driven vehicle, which describes the vehicle dynamics. The driver interface in a driving simulator is commonly similar to an actual vehicle with a steering wheel and accelerator and brake pedals, although different experimental settings can be freely tested within a simulator. The driver interface provides input to the physical model which uses these inputs to calculate vehicle responses, such as accelerations and velocities. The calculated motions by the physical model of the vehicle will be fed back to the driver in a moving base simulator. To do so specific strategies that consider the physical limitations of the moving base are required, which are called motion queueing. Also worth noting is that input to the physical model is not only the driver input, but also the surrounding world, e.g. slope and curvature of the road. Thus, for a total experience in a moving base driving simulator it is necessary to consider the whole chain, a driver in a certain driving scenario providing inputs, a physical model generating a dynamics response from the inputs, and realization of motion by motion cueing. A limitation in this work is that it does not include an investigation into the area of motion cueing. The reason for this is that the area is too vast to be included, considering the time constraints. However, different vehicles with different dynamic performances are expected to benefit from using different motion cueing algorithms or calibrations.

Physical modelling of the vehicle will typically use a representation of differential algebraic equations (DAE) combined with discrete events, e.g. when a driver changes gear. Modelling such systems can be done in several ways using many different tools. One straightforward method would be to use a procedural programming language, such as Fortran or $\mathrm{C} / \mathrm{C}++$, and let an engineer design how the equations will be solved by implementing a 
Table 1.1: A one tank system implemented in $\mathrm{C}++$ and Modelica omitting routines for initialization and set and get input and/or output.

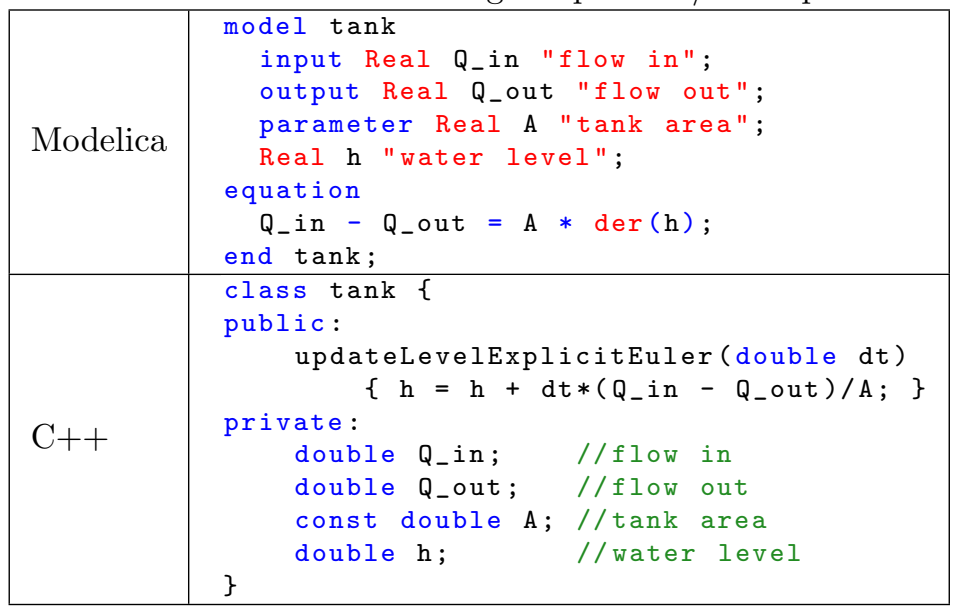

solver for the DAE system. Another approach would be to use a tool that provides a graphical user interface where the engineer can specify the flow of information in an input/output manner, an example of such a tool is Simulink from MathWorks. Here the task for the engineer is simpler since the solver is provided in Simulink. However, in such an approach the direction of information flow is embedded into the model which can be a drawback. Thus, one further approach is to reduce the manual work by letting the engineer write the equations directly and let the compiler sort the equations automatically, then using a numerical solver for solving the resulting system, e.g. DASSL which is a numerical solver for implicit systems of differential and algebraic equations (Petzold 1982). An example of a language to handle this type of modelling is the equation based language Modelica, see e.g. (Fritzson 2004) or (Modelica Association 2012). Modelica lets the modeler write acausal models and also includes a graphical user interface with a rich standard library of components. Modelica supports object-orientation, where a large model may be built from components, giving a high level of reusability. To give an example of the described modelling methods consider Table 1.1 where two implementations are presented, one in $\mathrm{C}++$ and one in Modelica. For the modelled system in $\mathrm{C}++$ the model will only solve for $\mathrm{h}$ while for the Modelica model the system could be changed by the compiler to be solved for e.g. Q_out if $\mathrm{h}$ were given depending on how the engineer uses the model. Relieving the developer of practical details such as implementing a solver for the DAE makes the acausal modelling attractive, but one drawback has been the difficulty in debugging such systems.

Another important aspect regarding physical modelling of dynamic systems, such as vehicles, is the evolution over time. In this aspect a dynamics 
model of a vehicle needs to evolve to keep a high level of fidelity over time. If development has been done over several years with a rich history there is a need to handle legacy code. Also, for future use it is good to consider modelling tools which are expected to respond well to changes within a dynamics model such as changing or modifying a submodel. As an example of how legacy code can evolve consider the early usage of moving base driving simulators at VTI where the vehicle dynamics model was programmed in Fortran together with the rest of the simulator software (Nordmark 1984). Limitations in model complexity were at that time the available computing power. Over the more than thirty years of development other programming languages have been introduced into the simulator software with the majority being $\mathrm{C}$ and further $\mathrm{C}++$, Simulink, Modelica, and XML with available libraries such as Boost, Qt and Simscape. The result is a heterogeneous simulator system with legacy hardware and software and when engineers implement or add new components the limitations are more due to the required implementation time, since powerful computers are relatively cheap.

In this work the approach has been to use Modelica, which is a modelling language with an emphasis on object oriented modelling and hybrid modelling (continuous and discrete time). Modelica is based on an open standard and has a large tool support. As a counter example consider for example Simulink where the internal description of the model is not freely available and thus the only tool that can handle the model is Simulink itself. As Modelica is a wide-spread language specification there are several different tools available that can transform a model into computable code, thus the user can freely choose tool depending on the application. One free and open source tool for Modelica is OpenModlica developed at Linköping University together with the Open Source Modelica Consortium (Open Source Modelica Consortium 2013). OpenModelica has support for almost the whole standard and the Modelica Standard Library and also has several extra features such as e.g. support for synchronous features, support for compiling Functional Mock-up Units (FMUs) according to the Functional Mock-up Interface (FMI) standard, a graphical user interface, and automatic parallelization with ParModelica.

The abovementioned FMI standard (Blochwitz et al. 2011) enables another way to collaborate using models. FMI is an open standard designed to provide efficient computing and supports both open models and black box models with or without an embedded numerical solver. Given correctly handled connections and a tool that supports the FMI standard an engineer can export and import FMUs into his/her models. Currently, one drawback with the FMI standard is the lack of a master algorithm that simulates several FMUs together since the execution order is important, considering that FMUs are not necessary acausal. The reason for this is that a user can include information into an FMU so that acausal modelling is possible, but it is not required by the standard. Moreover, for a black box FMU such information does not exist.

A further challenge is to run a physical dynamics model in the simulator 
environment where real-time performance is needed. For Matlab Simulink models a real-time environment called xPC-Target (Mosterman et al. 2005) can be used. Considering a Modelica model there are other approaches for connecting or interfacing the model to a moving base driving simulator environment. One approach is to compile a Modelica model into a Matlab Simulink model and then use an xPC-Target environment. Another solution is to generate $\mathrm{C} / \mathrm{C}++$ code and then link it directly into the simulator software kernel. Automatic generation of real-time code to a real-time environment is a convenient but currently costly method for the modeler. Thus, the chosen approach is tightly connected to the application.

\subsection{Hardware-In-the-Loop}

Hardware-In-the-Loop (HiL) is a method where hardware is interfaced into a software controlled environment/simulation using sensors and actuators. The purpose of introducing HiL can be seen from two perspectives, either the included hardware system is tested or the included hardware system provides extra fidelity to a software simulation. The closer to the final hardware production system the higher the probability is that the HiL system is correctly perceived and evaluated. Note that the hardware system does not need to be a production system but can be a small scale model such as a radio car instead of a car (Brennan and Alleyne 2000) or scaled down electronic components (Petersheim and Brennan 2009) where signals are scaled to resemble a full scale system. HiL is a very general term and the inclusion of hardware does not specify to which degree hardware has been used. For instance, it doesn't distinguish between a simulation that includes vehicle electronic control units (Alles et al. 1992) and when a radio car is included or a case where a complete car powertrain is included as in Paper C. To further specify what is meant by HiL other terms are sometimes used. For example within driving simulation the term human-in-the-loop is used at times. In this thesis such further specifying terms are avoided and instead HiL is used with a thorough description of the set-up. One important difference from other types of simulations is that a HiL simulation has real-time demands due to hardware response times. Thus, it can be difficult to do a simulation faster than real-time e.g. batch simulations and restarting a simulation can be time consuming since hardware needs time to get into a correct initial state.

For a moving base driving simulator the possibility to add hardware into the simulation is rather essential. For instance, consider the usage of a cabin which not only has the steering wheel and pedals but also contains a connection to the internal car CAN bus for in-vehicle buttons. It is advantageous to use a moving base simulator with HiL since it provides faster design cycles as well as providing a better fidelity for the driver without needing a prototype vehicle. However, HiL simulation requires an interface to ensure functionality between the hardware and the software model. This can 
be specifically tricky if the vehicle model has parts/submodels which are black box models that need to interact with the hardware e.g. when debugging erroneous output from a black box where internal states are unknown.

\subsection{Distributed Simulation}

Distributed simulation is a technique where different parts of a simulation at physically different locations are connected together over a network. Connecting systems over different networks increases the complexity of the simulation since added communication has to be managed. One major benefit of a distributed simulation is that systems at physically different locations which might not be possible to move can be connected. Thus, a distributed simulation might be the only enabler for performing certain simulation studies requiring specific accurate system set-ups. As an example consider the set-up presented in Paper A where a moving base simulator and chassis dynamometer laboratory are connected to each other. In such a case it is difficult to move either the moving base simulator or the chassis dynamometers. A negative aspect of distributed simulation is that delays are introduced which is an undesired property. The combination of distributed systems with real-time requirements present a particular challenge and techniques have been developed to deal with such set-ups in (Goodell et al. 2006) and (Ersal et al. 2011).

In this work different approaches to create a distributed simulation combined with HiL including moving base driving simulators are investigated. Different simulators have different purposes and different strategies have been tested to see how well different simulators can be combined in the existing literature. But little research exist on distributed simulation combined with moving base driving simulators. At VTI only one study has made a prototype implementation (Vinter 2010). The reason for this can be that the network inside the moving base driving simulator at VTI is contained and thus, when a simulation is started the simulator will be disconnected from the outside world protecting the simulator environment from disturbances. For a distributed simulation, there is a need to have an active connection to the outside world while the simulator is running. This can be sensitive since a moving base simulator have the capacity to present high accelerations to the driver and a higher level of security is needed. One of the few examples of a distributed simulation where connections were made over the internet combining an engine test lab and a moving base driving simulator can be found in (Brudnak et al. 2008). Distributed simulation has been used more in other fields, as an example for military applications High level architecture (HLA) has been used a lot for distributed simulations (Möller et al. 2008).

There can also be different subcomponents of a physical vehicle model which are simulated in a distributed platform. In such a case there is a tighter limit on the time delay that can be tolerated. Considering the update frequency in a driving simulator, the requirements at VTI are rather strict 
and a common case is a dynamics model update frequency of $1000 \mathrm{~Hz}$, which is needed for providing a good steering feel. Thus, a delay of one millisecond or more in communication would probably make the simulation unreliable and compromise the driver experience and the driver behavior.

\subsection{Contributions}

Combining HIL simulations and distributed simulations is an underexplored area. With regards to moving base driving simulators existing research is further limited. This thesis work investigates whether simulator fidelity can be maintained or improved with a more flexible and scalable simulator set-up. The contributions in this thesis are primarily presented in three papers. These papers discuss different extensions, both software and hardware, for distributed simulations of moving base driving simulators. There have also been two demonstrations performed of one of the developed distributed driving simulator set-ups.

Below, short introductions to each paper with a short description of the main results are given. The last section presents the performed demonstrations.

\subsubsection{Paper A}

Paper A presents a distributed co-simulation, connecting the moving base driving simulator Sim III at VTI to a vehicle connected to a chassis dynamometer at Vehicular Systems, Linköping University, a distance of approximately $500 \mathrm{~m}$. The paper presents how a pedal robot with actuators and sensors provides an interface between the driver in the simulator and the car. The fast communication of the platform enables the driver in the moving base driving simulator to drive a production vehicle at Vehicular Systems.

The purpose of this effort was to improve the driver perception of the powertrain in the moving base driving simulator. This first prototype achieved good and promising results and with further potential improvements it was concluded that adequate fidelity could be achieved for a realistic simulator case study. It was also the first time a car in a chassis dynamometer was driven by a driver in a moving base driving simulator.

\subsubsection{Paper B}

The co-simulation set-up described in Paper A requires that both the moving base driving simulator and the chassis dynamometer are available when developing or testing. If the complete co-simulation set-up is not available, but parts of it are, it can still be desirable to make experimentation possible. In this scope, Paper B investigates the potential of using Modelica for physical modeling of subsystems in such a distributed simulation. The objective is 
to be able to interchange software with hardware-in-the-loop, i.e. using the chassis dynamometer or a model thereof.

The presented Modelica models are evaluated using different solvers and are estimated to have real-time performance given a good run-time environment. The aim to add flexibility to the simulator set-up in Paper A was not entirely met but was seen as a promising work to continue.

\subsubsection{Paper C}

One further extension to a distributed moving base driving simulator is to use a standard for distributed simulation. In Paper $\mathrm{C}$ the usage of the IEEE standard HLA Evolved for moving base driving simulators is investigated. A distributed simulation architecture was designed and implemented, which divides a driving simulator environment into four major entities with welldefined interfaces, using HLA Evolved as the method of communication.

Results showed that original functionality was maintained while increasing flexibility, going from a smaller to a larger simulator, and adding scalability, possibility to add simulators to the same environment. The architecture provides clear interfaces between simulation entities. It was shown that approximately one millisecond overhead latency was added when using HLA, which was considered acceptable for the graphical system but needs more investigation for the interaction between the driver and the vehicle dynamics.

\subsubsection{Distributed Simulation Demonstrations}

The presented work in Paper $\mathrm{C}$ was extended by demonstrations with moving base driving simulators. Results with an active moving base could not be included in Paper C since the network was shut down for security reasons when operating the simulator. This issue for Sim II, Sim III and Sim IV was resolved during the months following the conference where Paper $\mathrm{C}$ was presented and two demonstrations were performed, one in Gothenburg and one in Linköping, which showed the complete architecture running. In Figure 1.1 the set-up used during the demonstration in Gothenburg is shown where the connection from Volvo Car Corporation (VCC) to VTI was set via a mobile phone due to VPN issues. The set-up used during the demonstration in Linköping is similar to the one in Gothenburg where instead the Sim IV and the VCC HiL simulators are replaced by Sim III and Sim II.

During both demonstrations, three vehicles, connected to different simulators, were driving within the same simulation scenario. At the demonstration in Gothenburg the vehicles were connected in the following way. One of the vehicles was driven by the driver in Sim IV with the moving base active. Another one was controlled from the VCC HIL simulator, and the last vehicle was driven via a desktop simulator with a gaming steering wheel set-up. The scenario started with the driver in Sim IV driving the leading car and the driver in the VCC HiL driving as a following car. The driver in the VCC HiL could choose to follow the lead vehicle by either driving manually or using 


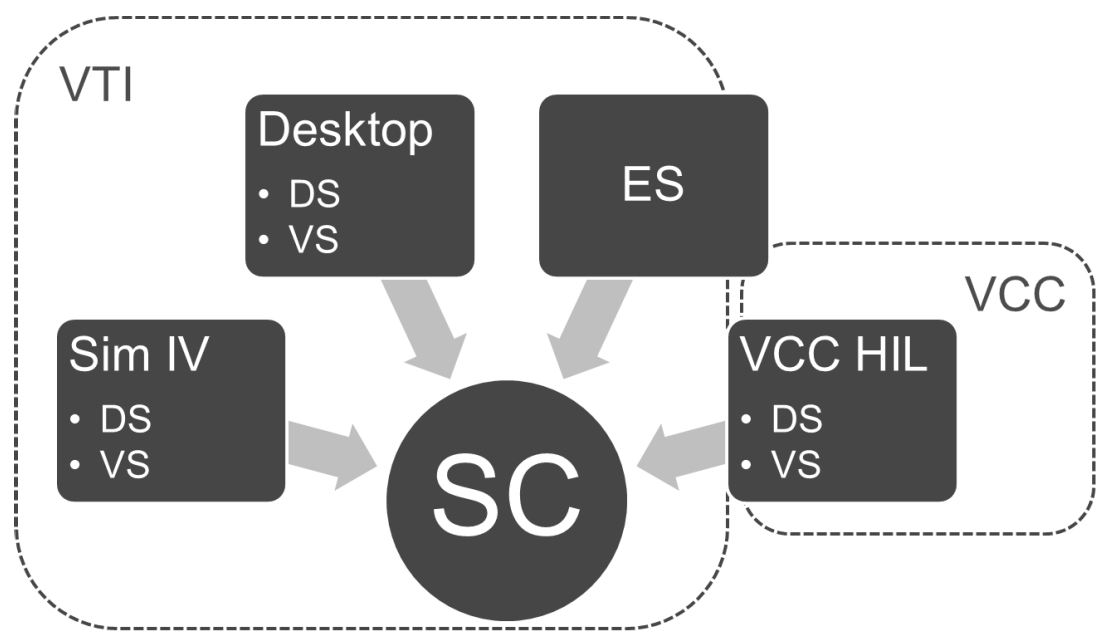

Figure 1.1: Simulator set-up used during demonstration of the developed HLA based simulation architecture in Gothenburg. SC, or Session Control, is controlling the simulation. ES, Environment Simulator, contains the road with its surrounding environment and vehicles. Sim IV, Desktop and VCC HiL are three different simulators.

an automatic cruise control (ACC) function in hardware. This demonstrated how a driver in Sim IV could interact with the driver in the VCC HiL simulator including hardware systems. During this part of the scenario the driver in the desktop simulator, controlling the third car, was driving around freely. After the car following part of the scenario the three vehicles were allowed to drive freely together. During the free driving part of the scenario the moving base of Sim IV was turned off so that more participants at the demonstration could try the set-up, as start and stop of the moving base takes time. In Linköping a similar set-up, but without the ACC hardware, was used with the simulators Sim II, Sim III and a desktop simulator.

The demonstrations showed working implementations of distributed simulations including hardware-in-the-loop and fully operational moving base driving simulators. From these demonstrations the following two conclusions could be drawn. Firstly, the simulator systems should be robust since during a simulation all participating simulators need to operate without issues. Here, every added simulator increases the risk of issues and thus adding a non-robust simulator will probably halt the complete simulation often. Secondly, it is important to have good insight into used network topology since hardware equipment at different companies can be protected and hard to reach by e.g. firewalls. For further information about the demonstrations, see (Andersson, Hultgren, et al. 2016). 


\subsection{Future Work}

As discussed in the introduction, with the increasing complexity of vehicles, accurate and versatile modelling and evaluation tools are needed to enable faster development cycles from first sketch to production vehicle. Also, from a national aspect accurate tools are needed as a research platform for achieving a safe and efficient transport system. As an example consider one important topic which is the gradually increasing autonomy in the traffic fleet. A lot of different levels of automation and drivers need to co-exist, which require a substantial technical development. One could then argue that with full autonomy the driver is not needed hence removing the need for driving simulators with drivers in the loop. On the other hand, the purpose of transportation is partially to move people. Thus, in many situations a human will be involved and it is still needed to study human behavior, e.g. regarding comfort. To summarize, it is believed that a moving base driving simulator is an important research tool which should adapt to future needs.

Issues noted in this work identify two directions for future work. One direction would be to create a real-time run-time environment for Modelica models. The run-time environment should be designed with drivers in the loop and contain support for hardware interfaces, e.g. providing access to device drivers for controlling actuators and sensors. Such a run-time environment could focus on Modelica models directly or could be based on open standards for models such as FMI. For recent work on device drivers in Modelica see (Thiele et al. 2017). The model implementation of the chassis dynamometer presented in this thesis has been compiled to a FMU using OpenModelica and it would thus be possible to test with both approaches. One example of usage for the presented work in this thesis could be distributed systems where a Modelica model and the hardware system can be interchanged. Another example is to artificially impose time delays and lost packages, during communication, and investigate how the distributed simulation reacts to such changes.

Another future direction would be to develop a requirement based assessment platform for simulator validity to detect errors, which otherwise can be time consuming and/or hard to detect. In a moving base driving simulator one complicating factor is that a human driver might adapt his/her behavior to compensate for such errors, making the error detection more difficult, as well as including unnatural driving behavior. As an example consider the update rate of the simulator kernel. If the update rate becomes slightly lower, a slow motion effect appears that could possibly change the driver behavior without the simulator operator noticing it. Other examples are errors in vehicle accelerations presented by the moving base, sound feedback and tactile feedback in the steering wheel. The requirements for such an assessment platform needs to be identified and applied to every model and submodel including hardware. If the complete model including communication complies with the requirements, certain simulator performance can 
be guaranteed. There is an ongoing work by the author in this direction. A method has been established to collect data for a specific vehicle model (Andersson, Kharrazi, et al. 2016). The collected data for one vehicle model has then been used to reason about validity before and during simulation, see (Andersson and Buffoni 2016) and (Andersson and Kharrazi 2016).

\section{$1.7 \quad$ References}

Ahlström, C., A. Bolling, G. Sörensen, O. Eriksson, and A. Andersson (2012). Validating speed and road surface realism in VTI driving simulator III. VTI rapport 745A. Swedish National Road and Transport Research Institute.

Alles, S., C. Swick, S. Mahmud, and F. Lin (1992). "Real time hardwarein-the-loop vehicle simulation". In: Instrumentation and Measurement Technology Conference, 1992. IMTC '92., 9th IEEE, pp. 159-164.

Andersson, A. and L. Buffoni (2016). "Powertrain Model Assesment for Different Driving Tasks through Requirement Verification". In: 9th EUROSIM Congress on Modelling and Simulation. Oulu, Finland.

Andersson, A., J. Andersson Hultgren, R. Leandertz, M. Johansson, S. Betnér, O. Jakobson, and F. Rolff (2016). SimArch 2 - Implementation and demonstration of the SimArch architecture. ViP publication 2016-2. Swedish National Road and Transport Research Institute.

Andersson, A. and S. Kharrazi (2016). "A Framework for Credibility Assessment of a Powertrain Model in Driving Simulator Studies". In: FISITA 2016 World Automotive Congress. Busan, Korea.

Andersson, A., S. Kharrazi, S. Lind, and A. Myklebust (2016). "Parameterization Procedure of a Powertrain Model for a Driving Simulator". In: Advances in Transportation Studies - An international Journal 2016 Special Issue 1, pp. 99-112.

Blissing, B. (2016). Driving in Virtual Reality: Investigations in Effects of Latency and Level of Virtuality. Teknologie Licentiat thesis. Linköping University, Sweden.

Blochwitz, T., M. Otter, and M. Arnold (2011). "The Functional Mockup Interface for Tool independent Exchange of Simulation Models". In: Proceedings of the 8th Modelica Conference. Dresden, Germany, pp. 105114.

Brennan, S. and A. Alleyne (2000). "The Illinois Roadway Simulator: A Mechatronic Testbed for Vehicle Dynamics and Control". In: IEEE/ASME Transactions on Mechatronics 5.4.

Brudnak, M., M. Pozolo, M. McGough, T. Mortsfield, A. Shvartsman, and R. Romano (2008). "Motion Base Simulation of a Hybrid-Electric HMMWV for Fuel Economy Measurement". In: SAE Int. J. Commer. Veh. 1.1, pp. $41-53$.

Ersal, T., M. Brudnak, A. Salvi, J. L. Stein, Z. Filipi, and H. K. Fathy (2011). "Development and model-based transparency analysis of an Internet- 
distributed hardware-in-the-loop simulation platform". In: Mechatronics 21.1.

Fischer, M., H. Sehammar, and G. Palmkvist (2010). "Motion cueing for 3-, 6- and 8-degrees-of-freedom motion systems". In: Driving simulation conference. Paris, France.

Fors, C., C. Ahlström, P. Sörner, J. Kovaceva, E. Hasselberg, M. Krantz, J.-F. Grönvall, K. Kircher, and A. Anund (2011). Camera-based sleepiness detection. ViP publication 2011-6. Swedish National Road and Transport Research Institute.

Fritzson, P. (2004). Principles of Object Oriented Modeling and Simulation with Modelica 2.1. Wiley-IEEE Press. ISBN: 0-471-471631.

Goodell, J., M. Compere, M. Simon, W. Smith, R. Wright, and M. Brudnak (2006). "Robust Control Techniques for State Tracking in the Presence of Variable Time Delays". In: SAE Technical Paper. SAE International.

Hansson, P., A. Stenbeck, A. Kusachov, F. Bruzelius, and B. Augusto (2015). "Prepositioning of driving simulator motion systems". In: International Journal of Vehicle Systems Modelling and Testing (IJVSMT) 10.3.

Jansson, J., J. Sandin, B. Augusto, and M. Fischer (2014). "Design and performance of the VTI Sim IV". In: Driving simulation conference. Paris, France.

Kircher, A., K. Kircher, J. Törnros, A. Bolling, L. Nilsson, C. Patten, T. Malmström, and R. Ceci (2004). Mobile telephone simulator study. VTI meddelande 969A. Swedish National Road and Transport Research Institute.

Markkula, G., O. Benderius, K. Wolff, and M. Wahde (2013). "Effects of experience and electronic stability control on low friction collision avoidance in a truck driving simulator". In: Accident Analysis and Prevention 50, pp. $1266-1277$.

Modelica Association (2012). Modelica Language Specification 3.3. www.modelica.org.

Möller, B., K. L. Morse, M. Lightner, R. Little, and R. Lutz (2008). "HLA Evolved - A Summary of Major Technical Improvements". In: Proceedings of the Fall 2008 Simulation Interoperability Workshop. Orlando FL, pp. 1519.

Mosterman, P. J., S. Prabhu, A. Dowd, J. Glass, T. Erkkinen, J. Kluza, and R. Shenoy (2005). "Embedded Real-Time Control via MATLAB, Simulink, and xPC Target". In: Handbook of Networked and Embedded Control Systems. Birkhäuser Boston, pp. 419-446.

NADS Overview PDF (2015). https://www.nads-sc.uiowa.edu/overview.php. NADS, The University of Iowa.

Nilsson, L. (1993). "Behavioural Research in an Advanced Driving Simulator - Experiences of the VTI System". In: Proceedings of the Human Factors and Ergonomics Society 37th Annual Meeting 1993. 
Nordmark, S. (1984). VTI Driving Simulator - Mathematical Model of a Four-wheeled Vehicle for Simulation in Real Time. VTI rapport 267A. Swedish National Road and Transport Research Institute.

- (1992). "The new Trygg Hansa truckdriving simulator: An advanced tool for research and training". In: Proceedings of the International Symposium on Advanced Vehicle Control 1992 (AVEC'92).

- (1994). Driving simulators, trends and experiences. VTI särtryck 204. Swedish National Road and Transport Research Institute.

Nordmark, S., H. Jansson, G. Palmkvist, and H. Sehammar (2004). "The new VTI Driving Simulator - Multi Purpose Moving Base with High Performance Linear Motion". In: Driving simulation conference. Paris, France.

Open Source Modelica Consortium (2013). OpenModelica Users Guide version 1.9.0beta. www.openmodelica.org.

Patten, C. and S. Mårdh (2012). Förbifart Stockholm - utvärdering av ett gestaltningsförslag för tunnel. VTI rapport 759. Swedish National Road and Transport Research Institute.

Petersheim, M. D. and S. Brennan (2009). "Scaling of hybrid-electric vehicle powertrain components for Hardware-in-the-loop simulation". In: Mechatronics - Special Issue on Hardware-in-the-loop simulation 19.7.

Petzold, L. R. (1982). "A description of DASSL: A differential/algebraic system solver". In: Scientific computing 1, pp. 65-68.

Rothhämel, M. (2013). "Characterisation and Utilisation of Steering Feel in Heavy Trucks". PhD thesis. Royal Institute of Technology, Sweden.

Thiele, B., T. Beutlich, V. Waurich, M. Sjölund, and T. Bellmann (2017). "Towards a Standard-Conform, Platform-Generic and Feature-Rich Modelica Device Drivers Library". In: 12th Int. Modelica Conference. Prague, Czech Republic.

Törnros, J., L. Harms, and H. Alm (1997). "The VTI driving simulator Validation studies". In: DSC97 - Driving simulation conference. Lyon, France.

Vinter, J. (2010). SimArch Final report. Tech. rep. Vinnova. 
Publications 



\section{Publications}

The articles associated with this thesis have been removed for copyright reasons.

For more details about these see:

http://urn.kb.se/resolve?urn=urn:nbn:se:liu:diva- 136146 


\section{Licentiate Theses}

\section{Linköpings Studies in Science and Technology Faculty of Arts and Sciences}

No 17

No 28

No 29

No 48

No 52

No 60

No 71

No 72

No 73

No 74

No 104

No 108

No 111

No 113

No 118

No 126

No 127

No 139

No 140

No 146

No 150

No 165

No 166

No 174

No 177

No 181

No 184

No 187

No 189

No 196

No 197

No 203

No 212

No 230

No 237

No 250

No 253

No 260

No 283

No 298

No 318

No 319

No 326

No 328

No 333

No 335

No 348

No 352

No 371

No 378

Vojin Plavsic: Interleaved Processing of Non-Numerical Data Stored on a Cyclic Memory. (Available at: FOA, Box 1165, S-581 11 Linköping, Sweden. FOA Report B30062E)

Arne Jönsson, Mikael Patel: An Interactive Flowcharting Technique for Communicating and Realizing Algorithms, 1984.

Johnny Eckerland: Retargeting of an Incremental Code Generator, 1984.

Henrik Nordin: On the Use of Typical Cases for Knowledge-Based Consultation and Teaching, 1985.

Zebo Peng: Steps Towards the Formalization of Designing VLSI Systems, 1985.

Johan Fagerström: Simulation and Evaluation of Architecture based on Asynchronous Processes, 1985.

Jalal Maleki: ICONStraint, A Dependency Directed Constraint Maintenance System, 1987.

Tony Larsson: On the Specification and Verification of VLSI Systems, 1986.

Ola Strömfors: A Structure Editor for Documents and Programs, 1986.

Christos Levcopoulos: New Results about the Approximation Behavior of the Greedy Triangulation, 1986.

Shamsul I. Chowdhury: Statistical Expert Systems - a Special Application Area for Knowledge-Based Computer Methodology, 1987.

Rober Bilos: Incremental Scanning and Token-Based Editing, 1987.

Hans Block: SPORT-SORT Sorting Algorithms and Sport Tournaments, 1987.

Ralph Rönnquist: Network and Lattice Based Approaches to the Representation of Knowledge, 1987.

Mariam Kamkar, Nahid Shahmehri: Affect-Chaining in Program Flow Analysis Applied to Queries of Programs, 1987.

Dan Strömberg: Transfer and Distribution of Application Programs, 1987.

Kristian Sandahl: Case Studies in Knowledge Acquisition, Migration and User Acceptance of Expert Systems, 1987.

Christer Bäckström: Reasoning about Interdependent Actions, 1988.

Mats Wirén: On Control Strategies and Incrementality in Unification-Based Chart Parsing, 1988.

Johan Hultman: A Software System for Defining and Controlling Actions in a Mechanical System, 1988.

Tim Hansen: Diagnosing Faults using Knowledge about Malfunctioning Behavior, 1988.

Jonas Löwgren: Supporting Design and Management of Expert System User Interfaces, 1989.

Ola Petersson: On Adaptive Sorting in Sequential and Parallel Models, 1989.

Yngve Larsson: Dynamic Configuration in a Distributed Environment, 1989.

Peter Åberg: Design of a Multiple View Presentation and Interaction Manager, 1989.

Henrik Eriksson: A Study in Domain-Oriented Tool Support for Knowledge Acquisition, 1989.

Ivan Rankin: The Deep Generation of Text in Expert Critiquing Systems, 1989.

Simin Nadjm-Tehrani: Contributions to the Declarative Approach to Debugging Prolog Programs, 1989.

Magnus Merkel: Temporal Information in Natural Language, 1989.

Ulf Nilsson: A Systematic Approach to Abstract Interpretation of Logic Programs, 1989.

Staffan Bonnier: Horn Clause Logic with External Procedures: Towards a Theoretical Framework, 1989.

Christer Hansson: A Prototype System for Logical Reasoning about Time and Action, 1990.

Björn Fjellborg: An Approach to Extraction of Pipeline Structures for VLSI High-Level Synthesis, 1990.

Patrick Doherty: A Three-Valued Approach to Non-Monotonic Reasoning, 1990.

Tomas Sokolnicki: Coaching Partial Plans: An Approach to Knowledge-Based Tutoring, 1990.

Lars Strömberg: Postmortem Debugging of Distributed Systems, 1990.

Torbjörn Näslund: SLDFA-Resolution - Computing Answers for Negative Queries, 1990.

Peter D. Holmes: Using Connectivity Graphs to Support Map-Related Reasoning, 1991.

Olof Johansson: Improving Implementation of Graphical User Interfaces for Object-Oriented Knowledge- Bases, 1991.

Rolf G Larsson: Aktivitetsbaserad kalkylering i ett nytt ekonomisystem, 1991.

Lena Srömbäck: Studies in Extended Unification-Based Formalism for Linguistic Description: An Algorithm for Feature Structures with Disjunction and a Proposal for Flexible Systems, 1992.

Mikael Pettersson: DML-A Language and System for the Generation of Efficient Compilers from Denotational Specification, 1992.

Andreas Kågedal: Logic Programming with External Procedures: an Implementation, 1992.

Patrick Lambrix: Aspects of Version Management of Composite Objects, 1992.

Xinli Gu: Testability Analysis and Improvement in High-Level Synthesis Systems, 1992.

Torbjörn Näslund: On the Role of Evaluations in Iterative Development of Managerial Support Systems, 1992.

Ulf Cederling: Industrial Software Development - a Case Study, 1992.

Magnus Morin: Predictable Cyclic Computations in Autonomous Systems: A Computational Model and Implementation, 1992.

Mehran Noghabai: Evaluation of Strategic Investments in Information Technology, 1993.

Mats Larsson: A Transformational Approach to Formal Digital System Design, 1993. 
Johan Ringström: Compiler Generation for Parallel Languages from Denotational Specifications, 1993. Michael Jansson: Propagation of Change in an Intelligent Information System, 1993.

Jonni Harrius: An Architecture and a Knowledge Representation Model for Expert Critiquing Systems, 1993.

Per Österling: Symbolic Modelling of the Dynamic Environments of Autonomous Agents, 1993.

Johan Boye: Dependency-based Groudness Analysis of Functional Logic Programs, 1993.

Lars Degerstedt: Tabulated Resolution for Well Founded Semantics, 1993.

Anna Moberg: Satellitkontor - en studie av kommunikationsmönster vid arbete på distans, 1993.

Peter Carlsson: Separation av företagsledning och finansiering - fallstudier av företagsledarutköp ur ett agentteoretiskt perspektiv, 1994.

Camilla Sjöström: Revision och lagreglering - ett historiskt perspektiv, 1994.

Cecilia Sjöberg: Voices in Design: Argumentation in Participatory Development, 1994.

Lars Viklund: Contributions to a High-level Programming Environment for a Scientific Computing, 1994.

Peter Loborg: Error Recovery Support in Manufacturing Control Systems, 1994.

Owen Eriksson: Informationssystem med verksamhetskvalitet - utvärdering baserat på ett verksamhetsinriktat och samskapande perspektiv, 1994.

Karin Pettersson: Informationssystemstrukturering, ansvarsfördelning och användarinflytande - En komparativ studie med utgångspunkt i två informationssystemstrategier, 1994.

Lars Poignant: Informationsteknologi och företagsetablering - Effekter på produktivitet och region, 1994.

Gustav Fahl: Object Views of Relational Data in Multidatabase Systems, 1994.

Henrik Nilsson: A Declarative Approach to Debugging for Lazy Functional Languages, 1994.

Jonas Lind: Creditor - Firm Relations: an Interdisciplinary Analysis, 1994.

Martin Sköld: Active Rules based on Object Relational Queries - Efficient Change Monitoring Techniques, 1994.

Pär Carlshamre: A Collaborative Approach to Usability Engineering: Technical Communicators and System Developers in Usability-Oriented Systems Development, 1994.

Stefan Cronholm: Varför CASE-verktyg i systemutveckling? - En motiv- och konsekvensstudie avseende arbetssätt och arbetsformer, 1994.

Mikael Lindvall: A Study of Traceability in Object-Oriented Systems Development, 1994.

Fredrik Nilsson: Strategi och ekonomisk styrning - En studie av Sandviks förvärv av Bahco Verktyg, 1994.

Hans Olsén: Collage Induction: Proving Properties of Logic Programs by Program Synthesis, 1994.

Lars Karlsson: Specification and Synthesis of Plans Using the Features and Fluents Framework, 1995.

Ulf Söderman: On Conceptual Modelling of Mode Switching Systems, 1995.

Choong-ho Yi: Reasoning about Concurrent Actions in the Trajectory Semantics, 1995.

Bo Lagerström: Successiv resultatavräkning av pågående arbeten. - Fallstudier i tre byggföretag, 1995.

Peter Jonsson: Complexity of State-Variable Planning under Structural Restrictions, 1995.

Anders Avdic: Arbetsintegrerad systemutveckling med kalkylprogram, 1995.

Eva L Ragnemalm: Towards Student Modelling through Collaborative Dialogue with a Learning Companion, 1995.

Eva Toller: Contributions to Parallel Multiparadigm Languages: Combining Object-Oriented and Rule-Based Programming, 1995.

Erik Stoy: A Petri Net Based Unified Representation for Hardware/Software Co-Design, 1995.

Johan Herber: Environment Support for Building Structured Mathematical Models, 1995.

Stefan Svenberg: Structure-Driven Derivation of Inter-Lingual Functor-Argument Trees for Multi-Lingual Generation, 1995.

Hee-Cheol Kim: Prediction and Postdiction under Uncertainty, 1995.

Dan Fristedt: Metoder i användning - mot förbättring av systemutveckling genom situationell metodkunskap och metodanalys, 1995.

Malin Bergvall: Syst
ansvarsroller, 1995 .

Joachim Karlsson: Towards a Strategy for Software Requirements Selection, 1995.

Jakob Axelsson: Schedulability-Driven Partitioning of Heterogeneous Real-Time Systems, 1995.

Göran Forslund: Toward Cooperative Advice-Giving Systems: The Expert Systems Experience, 1995.

Jörgen Andersson: Bilder av småföretagares ekonomistyrning, 1995.

Staffan Flodin: Efficient Management of Object-Oriented Queries with Late Binding, 1996.

Vadim Engelson: An Approach to Automatic Construction of Graphical User Interfaces for Applications in Scientific Computing, 1996.

Magnus Werner : Multidatabase Integration using Polymorphic Queries and Views, 1996.

Mikael Lind: Affärsprocessinriktad förändringsanalys - utveckling och tillämpning av synsätt och metod, 1996.

Jonas Hallberg: High-Level Synthesis under Local Timing Constraints, 1996.

Kristina Larsen: Förutsättningar och begränsningar för arbete på distans - erfarenheter från fyra svenska företag. 1996.

Mikael Johansson: Quality Functions for Requirements Engineering Methods, 1996.

Patrik Nordling: The Simulation of Rolling Bearing Dynamics on Parallel Computers, 1996.

Anders Ekman: Exploration of Polygonal Environments, 1996.

Niclas Andersson: Compilation of Mathematical Models to Parallel Code, 1996. 
Johan Jenvald: Simulation and Data Collection in Battle Training, 1996. Niclas Ohlsson: Software Quality Engineering by Early Identification of Fault-Prone Modules, 1996. Mikael Ericsson: Commenting Systems as Design Support-A Wizard-of-Oz Study, 1996. Jörgen Lindström: Chefers användning av kommunikationsteknik, 1996. Esa Falkenroth: Data Management in Control Applications - A Proposal Based on Active Database Systems, 1996.

Niclas Wahllöf: A Default Extension to Description Logics and its Applications, 1996.

Annika Larsson: Ekonomisk Styrning och Organisatorisk Passion - ett interaktivt perspektiv, 1997. Ling Lin: A Value-based Indexing Technique for Time Sequences, 1997.

Rego Granlund: $C^{3}$ Fire - A Microworld Supporting Emergency Management Training, 1997.

Peter Ingels: A Robust Text Processing Technique Applied to Lexical Error Recovery, 1997.

Per-Arne Persson: Toward a Grounded Theory for Support of Command and Control in Military Coalitions, 1997. Jonas S Karlsson: A Scalable Data Structure for a Parallel Data Server, 1997.

Carita Åbom: Videomötesteknik i olika affärssituationer - möjligheter och hinder, 1997.

Tommy Wedlund: Att skapa en företagsanpassad systemutvecklingsmodell - genom rekonstruktion, värdering och vidareutveckling i T50-bolag inom ABB, 1997.

Silvia Coradeschi: A Decision-Mechanism for Reactive and Coordinated Agents, 1997.

Jan Ollinen: Det flexibla kontorets utveckling på Digital - Ett stöd för multiflex? 1997.

David Byers: Towards Estimating Software Testability Using Static Analysis, 1997.

Fredrik Eklund: Declarative Error Diagnosis of GAPLog Programs, 1997.

Gunilla Ivefors: Krigsspel och Informationsteknik inför en oförutsägbar framtid, 1997.

Jens-Olof Lindh: Analysing Traffic Safety from a Case-Based Reasoning Perspective, 1997

Jukka Mäki-Turja:. Smalltalk - a suitable Real-Time Language, 1997.

Juha Takkinen: CAFE: Towards a Conceptual Model for Information Management in Electronic Mail, 1997.

Man Lin: Formal Analysis of Reactive Rule-based Programs, 1997.

Mats Gustafsson: Bringing Role-Based Access Control to Distributed Systems, 1997.

Boris Karlsson: Metodanalys för förståelse och utveckling av systemutvecklingsverksamhet. Analys och värdering av systemutvecklingsmodeller och dess användning, 1997.

Marcus Bjäreland: Two Aspects of Automating Logics of Action and Change - Regression and Tractability, 1998.

Jan Håkegård: Hierarchical Test Architecture and Board-Level Test Controller Synthesis, 1998.

Per-Ove Zetterlund: Normering av svensk redovisning - En studie av tillkomsten av Redovisningsrådets rekommendation om koncernredovisning (RR01:91), 1998.

Jimmy Tjäder: Projektledaren \& planen - en studie av projektledning i tre installations- och systemutvecklingsprojekt, 1998. 1998.

Tim Heyer: COMPASS: Introduction of Formal Methods in Code Development and Inspection, 1998.

Patrik Hägglund: Programming Languages for Computer Algebra, 1998.

Marie-Therese Christiansson: Inter-organisatorisk verksamhetsutveckling - metoder som stöd vid utveckling av partnerskap och informationssystem, 1998.

Christina Wennestam: Information om immateriella resurser. Investeringar i forskning och utveckling samt i personal inom skogsindustrin, 1998.

Joakim Gustafsson: Extending Temporal Action Logic for Ramification and Concurrency, 1998.

Henrik André-Jönsson: Indexing time-series data using text indexing methods, 1999.

Erik Larsson: High-Level Testability Analysis and Enhancement Techniques, 1998.

Carl-Johan Westin: Informationsförsörjning: en fråga om ansvar - aktiviteter och uppdrag i fem stora svenska organisationers operativa informationsförsörjning, 1998.

Åse Jansson: Miljöhänsyn - en del i företags styrning, 1998.

Thomas Padron-McCarthy: Performance-Polymorphic Declarative Queries, 1998.

Anders Bäckström: Värdeskapande kreditgivning - Kreditriskhantering ur ett agentteoretiskt perspektiv, 1998.

Ulf Seigerroth: Integration av förändringsmetoder - en modell för välgrundad metodintegration, 1999.

Fredrik Öberg: Object-Oriented Frameworks - A New Strategy for Case Tool Development, 1998.

Jonas Mellin: Predictable Event Monitoring, 1998.

Joakim Eriksson: Specifying and Managing Rules in an Active Real-Time Database System, 1998.

Bengt E W Andersson: Samverkande informationssystem mellan aktörer i offentliga åtaganden - En teori om aktörsarenor i samverkan om utbyte av information, 1998.

Pawel Pietrzak: Static Incorrectness Diagnosis of CLP (FD), 1999.

Tobias Ritzau: Real-Time Reference Counting in RT-Java, 1999.

Anders Ferntoft: Elektronisk affärskommunikation - kontaktkostnader och kontaktprocesser mellan kunder och leverantörer på producentmarknader, 1999.

Jo Skåmedal: Arbete på distans och arbetsformens påverkan på resor och resmönster, 1999.

Johan Alvehus: Mötets metaforer. En studie av berättelser om möten, 1999. 
Magnus Lindahl: Bankens villkor i låneavtal vid kreditgivning till högt belånade företagsförvärv: En studie ur ett agentteoretiskt perspektiv, 2000.

No 766

No 769

No 775

FiF-a 30

No 787

No 788

No 790

No 791

No 800

No 807

No 809

FiF-a 32

No 808

No 820

No 823

No 832

FiF-a 34

No 842

No 844

FiF-a 37

FiF-a 40

FiF-a 41

No. 854

No 863

No 881

No 882

No 890

FiF-a 47

No 894

No 906

No 917

No 916

FiF-a-49

FiF-a-51

No 919

No 915

No 931

No 933

No 938

No 942

No 956

FiF-a 58

No 964

No 973

No 958

FiF-a 61

No 985

No 982

No 989

No 990

No 991
Martin V. Howard: Designing dynamic visualizations of temporal data, 1999.

Jesper Andersson: Towards Reactive Software Architectures, 1999.

Anders Henriksson: Unique kernel diagnosis, 1999.

Pär J. Ågerfalk: Pragmatization of Information Systems - A Theoretical and Methodological Outline, 1999.

Charlotte Björkegren: Learning for the next project - Bearers and barriers in knowledge transfer within an organisation, 1999.

Håkan Nilsson: Informationsteknik som drivkraft i granskningsprocessen - En studie av fyra revisionsbyråer, 2000.

Erik Berglund: Use-Oriented Documentation in Software Development, 1999.

Klas Gäre: Verksamhetsförändringar i samband med IS-införande, 1999.

Anders Subotic: Software Quality Inspection, 1999.

Svein Bergum: Managerial communication in telework, 2000.

Flavius Gruian: Energy-Aware Design of Digital Systems, 2000

Karin Hedström: Kunskapsanvändning och kunskapsutveckling hos verksamhetskonsulter - Erfarenheter från ett FOU-samarbete, 2000

Linda Askenäs: Affärssystemet - En studie om teknikens aktiva och passiva roll i en organisation, 2000.

Jean Paul Meynard: Control of industrial robots through high-level task programming, 2000.

Lars Hult: Publika Gränsytor - ett designexempel, 2000

Paul Pop: Scheduling and Communication Synthesis for Distributed Real-Time Systems, 2000.

Göran Hultgren: Nätverksinriktad Förändringsanalys - perspektiv och metoder som stöd för förståelse och utveckling av affärsrelationer och informationssystem, 2000.

Magnus Kald: The role of management control systems in strategic business units, 2000.

Mikael Cäker: Vad kostar kunden? Modeller för intern redovisning, 2000.

Ewa Braf: Organisationers kunskapsverksamheter - en kritisk studie av "knowledge management", 2000.

Henrik Lindberg: Webbaserade affärsprocesser - Möjligheter och begränsningar, 2000.

Benneth Christiansson: Att komponentbasera informationssystem - Vad säger teori och praktik?, 2000.

Ola Pettersson: Deliberation in a Mobile Robot, 2000.

Dan Lawesson: Towards Behavioral Model Fault Isolation for Object Oriented Control Systems, 2000.

Johan Moe: Execution Tracing of Large Distributed Systems, 2001.

Yuxiao Zhao: XML-based Frameworks for Internet Commerce and an Implementation of B2B e-procurement, 2001.

Annika Flycht-Eriksson: Domain Knowledge Management in Information-providing Dialogue systems, 2001.

Per-Arne Segerkvist: Webbaserade imaginära organisationers samverkansformer: Informationssystemarkitektur och aktörssamverkan som förutsättningar för affärsprocesser, 2001.

Stefan Svarén: Styrning av investeringar i divisionaliserade företag - Ett koncernperspektiv, 2001.

Lin Han: Secure and Scalable E-Service Software Delivery, 2001.

Emma Hansson: Optionsprogram för anställda - en studie av svenska börsföretag, 2001

Susanne Odar: IT som stöd för strategiska beslut, en studie av datorimplementerade modeller av verksamhet som stöd för beslut om anskaffning av JAS 1982, 2002.

Stefan Holgersson: IT-system och filtrering av verksamhetskunskap - kvalitetsproblem vid analyser och beslutsfattande som bygger på uppgifter hämtade från polisens IT-system, 2001.

Per Oscarsson: Informationssäkerhet i verksamheter - begrepp och modeller som stöd för förståelse av informationssäkerhet och dess hantering, 2001.

Luis Alejandro Cortes: A Petri Net Based Modeling and Verification Technique for Real-Time Embedded Systems, 2001.

Niklas Sandell: Redovisning i skuggan av en bankkris - Värdering av fastigheter. 2001.

Fredrik Elg: Ett dynamiskt perspektiv på individuella skillnader av heuristisk kompetens, intelligens, mentala modeller, mål och konfidens i kontroll av mikrovärlden Moro, 2002.

Peter Aronsson: Automatic Parallelization of Simulation Code from Equation Based Simulation Languages, 2002.

Bourhane Kadmiry: Fuzzy Control of Unmanned Helicopter, 2002.

Patrik Haslum: Prediction as a Knowledge Representation Problem: A Case Study in Model Design, 2002.

Robert Sevenius: On the instruments of governance - A law \& economics study of capital instruments in limited liability companies, 2002.

Johan Petersson: Lokala elektroniska marknadsplatser - informationssystem för platsbundna affärer, 2002.

Peter Bunus: Debugging and Structural Analysis of Declarative Equation-Based Languages, 2002.

Gert Jervan: High-Level Test Generation and Built-In Self-Test Techniques for Digital Systems, 2002.

Fredrika Berglund: Management Control and Strategy - a Case Study of Pharmaceutical Drug Development, 2002.

Fredrik Karlsson: Meta-Method for Method Configuration - A Rational Unified Process Case, 2002.

Sorin Manolache: Schedulability Analysis of Real-Time Systems with Stochastic Task Execution Times, 2002.

Diana Szentiványi: Performance and Availability Trade-offs in Fault-Tolerant Middleware, 2002.

Iakov Nakhimovski: Modeling and Simulation of Contacting Flexible Bodies in Multibody Systems, 2002.

Levon Saldamli: PDEModelica - Towards a High-Level Language for Modeling with Partial Differential Equations, 2002.

Almut Herzog: Secure Execution Environment for Java Electronic Services, 2002. 
No 999

No 1000

No 1001

No 988

FiF-a 62

No 1003

No 1005

No 1008

No 1010

No 1015

No 1018

No 1022

FiF-a 65

No 1024

No 1034

No 1033

FiF-a 69

No 1049

No 1052

No 1054

FiF-a 71

No 1055

No 1058

FiF-a 73

No 1079

No 1084

FiF-a 74

No 1094

No 1095

No 1099

No 1110

No 1116

FiF-a 77

No 1126

No 1127

No 1132

No 1130

No 1138

No 1149

No 1156

No 1162

No 1165

FiF-a 84

No 1166

No 1167

No 1168

FiF-a 85

No 1171

FiF-a 86

No 1172

No 1183

No 1184

No 1185

No 1190

Jon Edvardsson: Contributions to Program- and Specification-based Test Data Generation, 2002.

Anders Arpteg: Adaptive Semi-structured Information Extraction, 2002.

Andrzej Bednarski: A Dynamic Programming Approach to Optimal Retargetable Code Generation for Irregular Architectures, 2002.

Mattias Arvola: Good to use! : Use quality of multi-user applications in the home, 2003.

Lennart Ljung: Utveckling av en projektivitetsmodell - om organisationers förmåga att tillämpa projektarbetsformen, 2003.

Pernilla Qvarfordt: User experience of spoken feedback in multimodal interaction, 2003.

Alexander Siemers: Visualization of Dynamic Multibody Simulation With Special Reference to Contacts, 2003.

Jens Gustavsson: Towards Unanticipated Runtime Software Evolution, 2003.

Calin Curescu: Adaptive QoS-aware Resource Allocation for Wireless Networks, 2003.

Anna Andersson: Management Information Systems in Process-oriented Healthcare Organisations, 2003.

Björn Johansson: Feedforward Control in Dynamic Situations, 2003.

Traian Pop: Scheduling and Optimisation of Heterogeneous Time/Event-Triggered Distributed Embedded Systems, 2003.

Britt-Marie Johansson: Kundkommunikation på distans - en studie om kommunikationsmediets betydelse i affärstransaktioner, 2003.

Aleksandra Tešanovic: Towards Aspectual Component-Based Real-Time System Development, 2003.

Arja Vainio-Larsson: Designing for Use in a Future Context - Five Case Studies in Retrospect, 2003.

Peter Nilsson: Svenska bankers redovisningsval vid reservering för befarade kreditförluster - En studie vid införandet av nya redovisningsregler, 2003.

Fredrik Ericsson: Information Technology for Learning and Acquiring of Work Knowledge, 2003.

Marcus Comstedt: Towards Fine-Grained Binary Composition through Link Time Weaving, 2003.

Åsa Hedenskog: Increasing the Automation of Radio Network Control, 2003.

Claudiu Duma: Security and Efficiency Tradeoffs in Multicast Group Key Management, 2003.

Emma Eliason: Effektanalys av IT-systems handlingsutrymme, 2003.

Carl Cederberg: Experiments in Indirect Fault Injection with Open Source and Industrial Software, 2003.

Daniel Karlsson: Towards Formal Verification in a Component-based Reuse Methodology, 2003.

Anders Hjalmarsson: Att etablera och vidmakthålla förbättringsverksamhet - behovet av koordination och interaktion vid förändring av systemutvecklingsverksamheter, 2004.

Pontus Johansson: Design and Development of Recommender Dialogue Systems, 2004.

Charlotte Stoltz: Calling for Call Centres - A Study of Call Centre Locations in a Swedish Rural Region, 2004.

Björn Johansson: Deciding on Using Application Service Provision in SMEs, 2004.

Genevieve Gorrell: Language Modelling and Error Handling in Spoken Dialogue Systems, 2004.

Ulf Johansson: Rule Extraction - the Key to Accurate and Comprehensible Data Mining Models, 2004.

Sonia Sangari: Computational Models of Some Communicative Head Movements, 2004.

Hans Nässla: Intra-Family Information Flow and Prospects for Communication Systems, 2004.

Henrik Sällberg: On the value of customer loyalty programs - A study of point programs and switching costs, 2004.

Ulf Larsson: Designarbete i dialog - karaktärisering av interaktionen mellan användare och utvecklare i en systemutvecklingsprocess, 2004.

Andreas Borg: Contribution to Management and Validation of Non-Functional Requirements, 2004.

Per-Ola Kristensson: Large Vocabulary Shorthand Writing on Stylus Keyboard, 2004.

Pär-Anders Albinsson: Interacting with Command and Control Systems: Tools for Operators and Designers, 2004.

Ioan Chisalita: Safety-Oriented Communication in Mobile Networks for Vehicles, 2004.

Thomas Gustafsson: Maintaining Data Consistency in Embedded Databases for Vehicular Systems, 2004.

Vaida Jakoniené: A Study in Integrating Multiple Biological Data Sources, 2005.

Abdil Rashid Mohamed: High-Level Techniques for Built-In Self-Test Resources Optimization, 2005.

Adrian Pop: Contributions to Meta-Modeling Tools and Methods, 2005.

Fidel Vascós Palacios: On the information exchange between physicians and social insurance officers in the sick leave process: an Activity Theoretical perspective, 2005.

Jenny Lagsten: Verksamhetsutvecklande utvärdering i informationssystemprojekt, 2005.

Emma Larsdotter Nilsson: Modeling, Simulation, and Visualization of Metabolic Pathways Using Modelica, 2005.

Christina Keller: Virtual Learning Environments in higher education. A study of students' acceptance of educational technology, 2005.

Cécile Åberg: Integration of organizational workflows and the Semantic Web, 2005.

Anders Forsman: Standardisering som grund för informationssamverkan och IT-tjänster - En fallstudie baserad på trafikinformationstjänsten RDS-TMC, 2005.

Yu-Hsing Huang: A systemic traffic accident model, 2005. transaktionsintensiva verksamheter, 2005.

Petter Ahlström: Affärsstrategier för seniorbostadsmarknaden, 2005.

Mathias Cöster: Beyond IT and Productivity - How Digitization Transformed the Graphic Industry, 2005.

Åsa Horzella: Beyond IT and Productivity - Effects of Digitized Information Flows in Grocery Distribution, 2005.

Maria Kollberg: Beyond IT and Productivity - Effects of Digitized Information Flows in the Logging Industry, 2005. 
Andreas Hansson: Increasing the Storage Capacity of Recursive Auto-associative Memory by Segmenting Data, 2005 .

No 1192 Nicklas Bergfeldt: Towards Detached Communication for Robot Cooperation, 2005.

No 1194 Dennis Maciuszek: Towards Dependable Virtual Companions for Later Life, 2005.

No 1204 Beatrice Alenljung: Decision-making in the Requirements Engineering Process: A Human-centered Approach, 2005 .

No 1206

No 1207

No 1209

Anders Larsson: System-on-Chip Test Scheduling and Test Infrastructure Design, 2005.

John Wilander: Policy and Implementation Assurance for Software Security, 2005.

Andreas Käll: Översättningar av en managementmodell - En studie av införandet av Balanced Scorecard i ett landsting, 2005.

No 1225 He Tan: Aligning and Merging Biomedical Ontologies, 2006.

No 1228 Artur Wilk: Descriptive Types for XML Query Language Xcerpt, 2006.

No 1229

No 1231

Per Olof Pettersson: Sampling-based Path Planning for an Autonomous Helicopter, 2006.

No 1233

Kalle Burbeck: Adaptive Real-time Anomaly Detection for Safeguarding Critical Networks, 2006.

Daniela Mihailescu: Implementation Methodology in Action: A Study of an Enterprise Systems Implementation Methodology, 2006.

No 1244 Jörgen Skågeby: Public and Non-public gifting on the Internet, 2006.

No 1248

No 1263

Karolina Eliasson: The Use of Case-Based Reasoning in a Human-Robot Dialog System, 2006.

FiF-a 90

No 1272

No 1277

No 1283

Misook Park-Westman: Managing Competence Development Programs in a Cross-Cultural Organisation - What are the Barriers and Enablers, 2006.

Amra Halilovic: Ett praktikperspektiv på hantering av mjukvarukomponenter, 2006.

Raquel Flodström: A Framework for the Strategic Management of Information Technology, 2006.

Viacheslav Izosimov: Scheduling and Optimization of Fault-Tolerant Embedded Systems, 2006.

Håkan Hasewinkel: A Blueprint for Using Commercial Games off the Shelf in Defence Training, Education and Research Simulations, 2006.

FiF-a 91

No 1286

No 1293

No 1302

No 1303

Hanna Broberg: Verksamhetsanpassade IT-stöd - Designteori och metod, 2006.

Robert Kaminski: Towards an XML Document Restructuring Framework, 2006.

Jiri Trnka: Prerequisites for data sharing in emergency management, 2007.

Björn Hägglund: A Framework for Designing Constraint Stores, 2007.

Daniel Andreasson: Slack-Time Aware Dynamic Routing Schemes for On-Chip Networks, 2007.

No 1305 Magnus Ingmarsson: Modelling User Tasks and Intentions for Service Discovery in Ubiquitous Computing, 2007.

No 1306

No 1307

No 1309

No 1312

No 1313

No 1317

No 1320

No 1323

Gustaf Svedjemo: Ontology as Conceptual Schema when Modelling Historical Maps for Database Storage, 2007.

Gianpaolo Conte: Navigation Functionalities for an Autonomous UAV Helicopter, 2007.

Ola Leifler: User-Centric Critiquing in Command and Control: The DKExpert and ComPlan Approaches, 2007.

Henrik Svensson: Embodied simulation as off-line representation, 2007.

Zhiyuan He: System-on-Chip Test Scheduling with Defect-Probability and Temperature Considerations, 2007.

Jonas EImqvist: Components, Safety Interfaces and Compositional Analysis, 2007.

Håkan Sundblad: Question Classification in Question Answering Systems, 2007.

Magnus Lundqvist: Information Demand and Use: Improving Information Flow within Small-scale Business Contexts, 2007.

No 1329

No 1331

Martin Magnusson: Deductive Planning and Composite Actions in Temporal Action Logic, 2007.

No 1332

No 1333

No 1337

Mikael Asplund: Restoring Consistency after Network Partitions, 2007.

Martin Fransson: Towards Individualized Drug Dosage - General Methods and Case Studies, 2007.

Karin Camara: A Visual Query Language Served by a Multi-sensor Environment, 2007.

David Broman: Safety, Security, and Semantic Aspects of Equation-Based Object-Oriented Languages and Environments, 2007.

No 1339

No 1351

No 1353

No 1356

No 1359

No 1361

No 1363

No 1371

No 1373

No 1381

No 1386

No 1387

No 1392

No 1393

No 1401

Mikhail Chalabine: Invasive Interactive Parallelization, 2007.

Susanna Nilsson: A Holistic Approach to Usability Evaluations of Mixed Reality Systems, 2008.

Shanai Ardi: A Model and Implementation of a Security Plug-in for the Software Life Cycle, 2008.

Erik Kuiper: Mobility and Routing in a Delay-tolerant Network of Unmanned Aerial Vehicles, 2008.

Jana Rambusch: Situated Play, 2008.

Martin Karresand: Completing the Picture - Fragments and Back Again, 2008.

Per Nyblom: Dynamic Abstraction for Interleaved Task Planning and Execution, 2008.

Fredrik Lantz: Terrain Object Recognition and Context Fusion for Decision Support, 2008.

Martin Östlund: Assistance Plus: 3D-mediated Advice-giving on Pharmaceutical Products, 2008.

Håkan Lundvall: Automatic Parallelization using Pipelining for Equation-Based Simulation Languages, 2008.

Mirko Thorstensson: Using Observers for Model Based Data Collection in Distributed Tactical Operations, 2008.

Bahlol Rahimi: Implementation of Health Information Systems, 2008.

Maria Holmqvist: Word Alignment by Re-using Parallel Phrases, 2008.

Mattias Eriksson: Integrated Software Pipelining, 2009.

Annika Öhgren: Towards an Ontology Development Methodology for Small and Medium-sized Enterprises, 2009.

No 1410 Rickard Holsmark: Deadlock Free Routing in Mesh Networks on Chip with Regions, 2009.

No 1421

No 1427

No 1450

No 1459

Sara Stymne: Compound Processing for Phrase-Based Statistical Machine Translation, 2009.

Tommy Ellqvist: Supporting Scientific Collaboration through Workflows and Provenance, 2009.

Fabian Segelström: Visualisations in Service Design, 2010.

Min Bao: System Level Techniques for Temperature-Aware Energy Optimization, 2010.

No 1466 Mohammad Saifullah: Exploring Biologically Inspired Interactive Networks for Object Recognition, 2011 
Qiang Liu: Dealing with Missing Mappings and Structure in a Network of Ontologies, 2011.

Ruxandra Pop: Mapping Concurrent Applications to Multiprocessor Systems with Multithreaded Processors and Network on Chip-Based Interconnections, 2011.

Per-Magnus Olsson: Positioning Algorithms for Surveillance Using Unmanned Aerial Vehicles, 2011.

Anna Vapen: Contributions to Web Authentication for Untrusted Computers, 2011.

Loove Broms: Sustainable Interactions: Studies in the Design of Energy Awareness Artefacts, 2011.

Johan Blomkvist: Conceptualising Prototypes in Service Design, 2011.

Håkan Warnquist: Computer-Assisted Troubleshooting for Efficient Off-board Diagnosis, 2011.

Jakob Rosén: Predictable Real-Time Applications on Multiprocessor Systems-on-Chip, 2011.

Usman Dastgeer: Skeleton Programming for Heterogeneous GPU-based Systems, 2011.

David Landén: Complex Task Allocation for Delegation: From Theory to Practice, 2011.

Kristian Stavåker: Contributions to Parallel Simulation of Equation-Based Models on

Graphics Processing Units, 2011.

Mariusz Wzorek: Selected Aspects of Navigation and Path Planning in Unmanned Aircraft Systems, 2011.

Piotr Rudol: Increasing Autonomy of Unmanned Aircraft Systems Through the Use of Imaging Sensors, 2011.

Anders Carstensen: The Evolution of the Connector View Concept: Enterprise Models for Interoperability Solutions in the Extended Enterprise, 2011.

Jody Foo: Computational Terminology: Exploring Bilingual and Monolingual Term Extraction, 2012.

Anders Fröberg: Models and Tools for Distributed User Interface Development, 2012.

Dimitar Nikolov: Optimizing Fault Tolerance for Real-Time Systems, 2012.

Dennis Andersson: Mission Experience: How to Model and Capture it to Enable Vicarious Learning, 2013.

Massimiliano Raciti: Anomaly Detection and its Adaptation: Studies on Cyber-physical Systems, 2013.

Banafsheh Khademhosseinieh: Towards an Approach for Efficiency Evaluation of Enterprise Modeling Methods, 2013.

Amy Rankin: Resilience in High Risk Work: Analysing Adaptive Performance, 2013.

Martin Sjölund: Tools for Understanding, Debugging, and Simulation Performance Improvement of EquationBased Models, 2013.

Karl Hammar: Towards an Ontology Design Pattern Quality Model, 2013.

Maria Vasilevskaya: Designing Security-enhanced Embedded Systems: Bridging Two Islands of Expertise, 2013. Ekhiotz Vergara: Exploiting Energy Awareness in Mobile Communication, 2013.

Valentina Ivanova: Integration of Ontology Alignment and Ontology Debugging for Taxonomy Networks, 2014.

Dag Sonntag: A Study of Chain Graph Interpretations, 2014.

Kiril Kiryazov: Grounding Emotion Appraisal in Autonomous Humanoids, 2014.

Zlatan Dragisic: Completing the Is-a Structure in Description Logics Ontologies, 2014.

Erik Hansson: Code Generation and Global Optimization Techniques for a Reconfigurable PRAM-NUMA Multicore Architecture, 2014.

Nicolas Melot: Energy-Efficient Computing over Streams with Massively Parallel Architectures, 2015.

Mahder Gebremedhin: Automatic and Explicit Parallelization Approaches for Mathematical Simulation Models, 2015.

Mikael Nilsson: Efficient Temporal Reasoning with Uncertainty, 2015.

Vladislavs Jahundovics: Automatic Verification of Parameterized Sytems by Over-Approximation, 2015.

Camilla Kirkegaard: Adding Challenge to a Teachable Agent in a Virtual Learning Environment, 2016.

Vengatanathan Krishnamoorthi: Efficient and Scalable Content Delivery of Linear and Interactive Branched Videos, 2016.

Andreas Löfwenmark: Timing Predictability in Future Multi-Core Avionics Systems, 2017.

Anders Andersson: Extensions for Distributed Moving Base Driving Simulators, 2017. 